\title{
Abolishing Infringement Jurisdiction for EU Marks? - The Perfume Marks Decision by the German Federal Court of Justice
}

\author{
Annette Kur
}

Published online: 12 April 2018

(C) The Author(s) 2018

\begin{abstract}
In its decision of 9 November 2017 the German Federal Court of Justice held that jurisdiction based on Art. 125(5) EUTMR is only vested in the courts at the place where, based on an overall assessment, the initial cause was set for the individual acts of infringement occurring in multiple Member States. The decision mixes up previous CJEU decisions dealing with international jurisdiction and applicable law. It could have serious repercussions in practice, as it amounts to discarding or at least seriously curtailing infringement jurisdiction based on Art. 125(5) as an alternative to the venues of central jurisdiction listed in Art. 125(1)-(4) EUTMR. In view of the serious consequences, the issue should at least have been referred to the CJEU.
\end{abstract}

Keywords International jurisdiction - Infringement of EU trade marks · Brussels Regulation · Jurisdiction and applicable law

\section{Introduction}

In Coty v. First Note ${ }^{1}$ the CJEU held that (then) Art. 93(5) CTMR ${ }^{2}$ only establishes tort jurisdiction at the place where an alleged CTM infringer has "acted". In

\footnotetext{
1 Case C-360/12, ECLI:EU:C:2014:1318 - Coty Germany GmbH v. First Note Perfumes NV.

${ }^{2}$ Regulation (EEC) No. 40/1994 on the Community Trade Mark. The numbering was subsequently changed into Art. 97(5) Regulation (EC) No. 207/2009 on the Community Trade Mark (consolidated version) and now appears as Art. 125(5) of Regulation (EU) No. 1001/2017 on the European Union Trade Mark. The contents of the provision have remained the same throughout these changes. This article refers to Art. 125(5) EUTMR unless previous case law dealing with Art. 93(5) or 97(5) CTMR is quoted or otherwise directly referred to.
}

A. Kur $(\bowtie)$

Prof. Dr. Dr. h.c., affiliated fellow

Max Planck Institute for Innovation and Competition, Munich, Germany

e-mail: annette.kur@ip.mpg.de 
Nintendo, ${ }^{3}$ the CJEU found that the law of the country "in which the act of infringement was committed" under Art. 8(2) Rome II Regulation ${ }^{4}$ refers to the country "where the event giving rise to the damage occurred". In a recent decision by the German Federal Court of Justice (Bundesgerichtshof, BGH) the statements made in both decisions were conflated to the effect that tort jurisdiction based on Art. 125(5) EUTMR is only held to be vested in the courts at the place where, based on an overall assessment, the initial cause was set for the individual acts of infringement occurring in multiple Member States. ${ }^{5}$ The decision is highly problematic. Different from what is claimed by the BGH, previous CJEU case law does not compel such an interpretation of Art. 125(5) EUTMR. At the very least, the BGH should have referred the issue to the CJEU for clarification.

When it was written, the aim of this note was to alert a larger audience to this development in German jurisprudence and the repercussions for infringement jurisdiction it entails, in the hope that this might motivate another court to send the open questions to the CJEU, where they belong. It turned out that such an alert was not necessary - in the meantime the Court of Appeal for England and Wales (Kitchin LJ) in AMS Neve Ltd and Ors v. Heritage Audio and Anor ${ }^{6}$ did exactly what the BGH failed to do. Thus, the purpose of this note has changed into adding some thoughts to what is aptly pointed out by Lord Justice Kitchin in paragraphs 57-59 of the appeal court's decision.

\section{The BGH's Perfume Marks Decision}

\subsection{Background and Reasoning}

The background of the case decided by the BGH was as follows. The defendants, domiciled in Italy, had provided a firm (H.P. ${ }^{7}$ ) in Germany with price lists and inventories of goods they had in stock, most of them bearing IR marks with Unionwide protection. The firm bought products from the defendants, brought them into Germany and stored them there. The plaintiffs contended that the goods had not been released on the EU market by, or with the consent of, the trade mark proprietor. They filed suit in Munich for infringement of the trade mark attached to the goods sold to H.P. and for threatening infringement of other marks contained in the lists provided to H.P. The defendants contested jurisdiction. The Munich district court, acting as a Union trade mark court of first instance, declined jurisdiction and

\footnotetext{
3 Joined cases C-24/16 and C-25/16, ECLI:EU:C:2017:724 - Nintendo Co. Ltd v. BigBen Interactive $\mathrm{GmbH}$ and BigBen Interactive SA.

${ }^{4}$ Regulation (EC) No. 864/2007 of the European Parliament and of the Council of 11 July 2007 on the law applicable to non-contractual obligations (Rome II).

5 German Federal Court of Justice (Bundesgerichtshof, BGH), decision of 9 November 2017, case No. I ZR 164/16 - Parfummarken (Perfume Marks), GRUR 2018, p. 84; for a translation of this decision into English see this issue of IIC at https://doi.org/10.1007/s40319-018-0700-8.

6 Decision of 1 February 2018, [2018] EWCA Civ 86. The case is pending before the CJEU as C-172/18.

7 It is a peculiarity of German court decisions that for reasons of data and privacy protection names are never fully indicated.
} 
rejected the claim. The Munich appeal court held that by providing the price lists and other information to H.P., the defendants had offered the goods for sale in Germany, thereby committing an "act of infringement". 8 By contrast, the appeal court found that the fact that the defendants had set up a website which could be accessed from Germany was not sufficient for establishing jurisdiction, as the website was not interactive so that no orders could be placed there.

The BGH quashed the appeal court's decision and restored the district court's judgment. Moreover, the BGH declared that the result would have been the same even if the defendants' website had been interactive. In support of its decision the BGH refers to Nintendo, where the CJEU held that

where the same defendant is accused of various acts of infringement committed in various Member States, the correct approach for identifying the event giving rise to the damage is not to refer to each alleged act of infringement, but to make an overall assessment of that defendant's conduct in order to determine the place where the initial act of infringement at the origin of that conduct was committed or threatened by it. ${ }^{9}$

Pursuant to the BGH it makes no difference that Nintendo was about Community design infringement and applicable law; it is taken for granted that for reasons of legal certainty the interpretation of Art. 8(2) Rome II and Art. 125(5) EUTMR must be the same. This is declared to be "not subject to doubt" ("nicht zweifelhaft"), rendering a referral to the CJEU unnecessary.

\subsection{Critique}

The BGH's reasoning is not convincing. It is true that Art. 8(2) Rome II regularly ${ }^{10}$ requires an overall assessment for identifying a single law applying in case of infringement of unitary intellectual property (IP) rights - whether they be EU marks, Community designs, or other Union rights. However, the BGH's contention that the concept proclaimed in Nintendo for determining the law applicable to infringement claims must also pertain to the identification of the court(s) competent to adjudicate such claims is far from not being subject to doubt - in fact, it must be seriously questioned.

Postulating such a parallel ignores the substantial structural and systematic differences between the two provisions. Article 8(2) Rome II primarily points to the application of uniform law as set forth in the EUTMR. Only where gaps are left in the EUTMR (for instance, in regard to ancillary sanctions such as computation of damages etc.) is the issue governed by the law at the place of infringement. It was unclear whether that meant that a mosaic approach must be applied or whether a uniform point of attachment can be identified. As is well known, the CJEU in Nintendo endorsed the latter option, which is more appropriate to the system of unitary rights than a fragmented approach.

\footnotetext{
${ }^{8}$ Munich Court of Appeal, decision of 23 June 2016, case No. 6 U 3129/15.

9 Nintendo (supra note 3), para. 111.

${ }^{10}$ Unless the initial event takes place in a non-EU country; see infra, 3.4.
} 
Regarding jurisdiction, the situation is completely different. The purpose of Art. 125(5) EUTMR is to provide an alternative to the venues listed in Art. 125(1)-(4). As a corollary, courts at the place where the act of infringement occurred are only competent to adjudicate on infringement within their own territory (Art. 126(2) EUTMR), while the courts at the "central venues" listed in Art. 125(1)-(4) have Union-wide competence. This demonstrates that Art. 125(5) is not about identifying a single, central linking factor for establishing jurisdiction. On the contrary - this is about the option to choose a "decentralised" venue, at the price of territorially limited competence. Contending that the only competent venue under Art. 125(5) EUTMR is the place where the initial act triggering further acts of infringement in other Member States was committed apparently clashes with the very aim of the provision.

\subsection{Consequences}

In the case decided by the $\mathrm{BGH}$ the result was that the infringement claim could only be raised in Italy, where the defendants had initially acted. As the defendants are also domiciled in Italy, Italian courts are competent anyhow on the basis of Art. 125(1) EUTMR, with jurisdiction being territorially unrestricted. In that situation, Art. 125(5) cannot fulfil its role of providing an alternative venue; the provision, including its special feature of territorial restriction, becomes moot.

The same result will regularly ensue when a defendant is domiciled or, without being domiciled, has an establishment in the EU. Based on the overall assessment required by the $\mathrm{BGH}$, the initial act of infringement typically occurs where the defendant conducts its central business activities, which regularly coincides with its seat or establishment, making Art. 125(5) practically obsolete. Furthermore, if the defendant's domicile and main place of business lie outside the EU, an overall assessment will often lead to the conclusion that the place of the initial act is not located in an EU Member State, meaning that Art. 125(5) EUTMR cannot be applied at all. ${ }^{11}$ The only remaining cases of relevance are those when a defendant domiciled in the EU initiates infringements from a different Member State, for instance from a local branch established there. ${ }^{12}$ While that leaves a certain margin of application so that the provision does not become completely meaningless, it seriously curtails the choice of venues available in case of EUTM infringement.

\footnotetext{
11 Of course in such cases the possibility remains to instigate proceedings at a venue of central competence, which in the scenario addressed above would be the plaintiff's domicile or establishment, if they lie in the EU, or the Spanish courts, or another venue that the parties have agreed on. Although major prejudice for the holders of Union marks can thus be prevented, the fact that a jurisdictional option specifically provided by the legislature cannot be applied at all in certain situations appears troubling.

12 To some extent this constitutes a parallel to Art. 7(5) of Regulation (EU) No. 1215/2012 on jurisdiction and the recognition and enforcement of judgments in civil and commercial matters (Brussels $\mathrm{I}^{\mathrm{a}}$ ). However, unlike that provision, the territorial effect of claims brought at the place of an establishment under Art. 125(5) EUTMR remains restricted to the forum state; there is no possibility for the court seized to adjudicate on the (other) infringements triggered.
} 


\section{Background and Further Considerations}

\subsection{Coty v. First Note: The CJEU's Take on Art. 125(5) EUTMR}

The Perfume Marks decision by the BGH is all the more remarkable because the opposite position was endorsed in the BGH's referral to the CJEU of the questions posed in Coty v. First Note. ${ }^{13}$ It was held in that decision that in the underlying dispute - concerning participation in an infringement allegedly committed in Germany by a defendant who solely acted in Belgium - jurisdiction of the German courts was warranted on the basis of Art. 97(5) CTMR (then: Art. 93(5) CTMR). The Coty referral decision also implies that the $\mathrm{BGH}$ would not have doubted the competence of the German CTM courts if the defendant had acted by delivering the impugned goods to Germany, without being physically present there.

The arguments proffered by the BGH in favour of the German courts' competence were refuted by the CJEU. The Court first pointed out that Art. 93(5) CTMR must be interpreted autonomously, and that the duality of linking factors developed under Art. 5(3) Brussels Convention ${ }^{14}$ cannot automatically apply to the interpretation of "the Member State in which the act of infringement has been committed or threatened". ${ }^{15}$ Whether or not such duality applies must be determined with account being taken of not only the wording, but also the context and purpose of the provision. ${ }^{16}$ On that basis, the CJEU concluded with reference to the wording ("act of infringement") that the linking factor under that provision relates to active conduct on the part of the person causing that infringement, and that therefore the provision "refers to the Member State where the act giving rise to the alleged infringement occurred or may occur, not the Member State where that infringement produces its effects". ${ }^{17}$

The Coty decision is not completely convincing either. It is certainly true that an autonomous interpretation of the provision is called for. As pointed out by Advocate General Jääskinen (cited with approval by the $\mathrm{CJEU}^{18}$ ), it was emphasised early-on during the legislative process that establishing separate, autonomous jurisdiction rules for CTMs is a necessity. ${ }^{19}$ The CJEU would therefore have been well-advised to interpret Art. 93(5) in a truly autonomous fashion, conceptualising "act of infringement" in the light of the legislation of which it forms a part. Unfortunately,

\footnotetext{
13 Decision of 28 June 2012, case No. I ZR 1/11 - Parfumflacons II (Perfume Flacons II), GRUR 2012, p. 1065 .

14 Corresponding to Art. 5(3) of Regulation (EC) No. 44/2001 on jurisdiction and the recognition and enforcement of judgments in civil and commercial matters (Brussels Regulation) and Art. 7(2) Brussels $\mathrm{I}^{\mathrm{a}}$ Regulation.

15 Coty v. First Note (supra note 1), paras. 31, 32.

16 Ibid., para. 33.

17 Ibid, para. 34.

18 Ibid., para. 36.

19 Opinion of Advocate General Jääskinen in case C-360/12, ECLI:EU:C:2013:764, Coty v. First Note, para. 28. The need for specific, autonomous rules is already confirmed by the fact that, under the Brussels system, alleged infringers operating from outside the EU would be subject to diverse national laws rather than a common system.
} 
however, the CJEU continued reading the provision through the lenses of general tort law and the jurisprudence established on the basis of Art. 5(3) of the Brussels Convention. Thus, the Court confined its analysis to the question of whether the dual linking factors developed on that basis, the "place of acting" and the "place of effect", also apply to Art. 93(5) CTMR. ${ }^{20}$ The CJEU thereby failed to realise that a more fundamental question needs to be answered first, namely whether and how the dichotomy of "act" and "effect" works in the context of intellectual property. Considering that question might have produced the insight that due to the territoriality principle it is not conceivable that infringing acts committed in one country produce (legally relevant) effects in another one. For such effects to arise it is always necessary that the infringer's conduct conforms to the prerequisites of an infringement committed in the same territory. For instance, selling goods in a state where they infringe a trade mark right is never a mere "effect" of those goods having been produced and divulgated in another state; it is a separate infringement predicated on commercial use made of the goods (or rather the sign attached to them) in the territory where the violation of the right is claimed to occur.

The fundamental difference vis-à-vis general tort law reflected therein causes ambiguities when the term "act" (of infringement) is used. ${ }^{21}$ "Act" can denote the initial conduct triggering further (legally independent) infringements in other territories, but it can also refer to conduct localised in the country where those individual infringements are committed. Both could be labelled "active conduct" for instance, offering goods for sale in a particular country and shipping them to customers located there certainly amounts to a person being "commercially active" in that territory. This raises the question whether the CJEU in Coty was aware of the ambiguity and the need resulting therefrom to distinguish between different forms of acting. Furthermore, it must be asked whether the consequence to be drawn from Coty is that in order to qualify as "active conduct" within the meaning intended by the CJEU the action must be physical, so that as a minimum requirement for establishing jurisdiction the defendant must be physically present at the place where an infringing act is committed or threatening. ${ }^{22}$

If such thoughts and intentions should have guided the decision in Coty they were at least not articulated explicitly. The decision thus leaves room for interpretation. And, to put it in the CJEU's own words, that interpretation should take account "not only of the wording, but also the context and purpose of the provision", ${ }^{23}$ including the legal history.

\footnotetext{
${ }^{20}$ That the CJEU had difficulties detaching itself from thinking "outside the box" of Art. 5(3) Brussels Convention is also demonstrated by the argument proffered ibid., para. 35, that "the existence of jurisdiction under Article 93(5) based on the place where the alleged infringement produces its effects would conflict with the wording of Article 94(2) of that regulation, which limits the jurisdiction of Community trade mark courts under Article 93(5) to acts committed or threatened in the Member State where the court seised is situated". If, in accordance with the position endorsed in this article, "act of infringement" is understood as infringing conduct (necessarily) localised in the territory where an individual infringement occurs, the "conflict" perceived by the CJEU evaporates.

21 For a more detailed analysis, see Kur (2015), pp. 468-480.

22 This seems to be the minimum requirement: the action must be "physical", which means that the defendant has to be present.

23 Coty v. First Note (supra note 1), para. 33.
} 


\subsection{Interpreting Art. 125(5) EUTMR: The Guiding Factors}

\subsubsection{Legal History}

As pointed out above, it was understood from the beginning that a system of unitary rights needs its own special rules of jurisdiction. This is spelled out in the first documents issued by the European Commission addressing the contents and structure of a future Community mark system. As was also explained in those documents, ${ }^{24}$ the blue-print for that system was found in Art. 69 of the 1975 Community Patent Convention (CPC). ${ }^{25}$ Pursuant to that provision, "[a]ctions for infringement of a Community patent may also be heard before the courts of a Contracting State in which an act of infringement was committed. The court hearing the action shall have jurisdiction only in respect of acts committed within the territory of that State". By making reference to "actions for infringement", the provision pertains to the violation of rights conferred by a Community patent as set forth in Arts. 28 and 29 CPC. This concerns inter alia the "making, offering, putting on the market or using a product which is the subject-matter of the patent, or importing or stocking the product for these purposes". ${ }^{26}$ There is nothing in the provision to suggest that if infringing products were found on the market in a Member State to which they had been shipped by the defendant this should not be considered as an act of "putting on the market", and thus an "act of infringement" within the meaning of the provision, unless the defendant was present in that state at the time of divulgation of the goods. ${ }^{27}$

When the model was adopted for constructing the CTM Regulation, there was also no discussion about restricting tort jurisdiction in the CTM context to conduct requiring the defendant's physical presence. That such an intention existed - or that it should even have been deliberately expressed in the wording - can be excluded with some certainty inter alia because the fathers of the Regulation had a keen interest in making the new system attractive for users. That goal is seriously jeopardised when insistence on qualifying elements, such as physical presence, results in conspicuous procedural disadvantages for the proprietors of unitary rights as compared to the owners of national rights. Instead of corroborating the position that the interpretation of what is regarded as an "act of infringement" in the context of Art. 125(5) is subject to qualifications, the legal history is therefore rather counter-indicative of any requirements other than that of an alleged infringement taking place in the forum state.

\footnotetext{
${ }^{24}$ Memorandum on the creation of an EEC trade mark adopted by the Commission on 6 July 1976, SEC(76) 2462, p. 481, para. 155.

25 Convention for the European Patent for the Common Market (Community Patent Convention), 76/76 EEC. Due to lacking ratification by a number of Member States the Convention never went into force.

26 Article 28 lit. a CPC (direct infringement of product patents). Corresponding provisions were stipulated for direct infringement of process patents and of products directly obtained by a protected process (Art. 28 lit. b and c CPC) and for indirect patent infringement (Art. 29 CPC).

27 It is true, of course, that at the relevant time - the early 1970s - the possibilities of incorporeal communication were not comparable to the situation of today. However, it was also not an unrealistic scenario at that time that goods were commercialised on different national markets.
} 


\subsubsection{Justification by Overarching Principles?}

Apart from the legal history, it must be considered whether requiring conduct qualified by the physical presence of the defendant can be justified by overarching considerations typically supporting the allocation of jurisdiction to specific venues, such as the sound administration of justice and efficacious conduct of proceedings. This would be the case in particular if, for example, the presence of the defendant in the forum state were crucial in relation to the evidence needed to assess the merits of the claim. It is true that, for instance, witnesses who saw the defendant act might be easier to find in the country where he or she was present at the relevant time. On the other hand, such evidence is not more conducive to the efficiency of proceedings than evidence concerning the market situation and perception of the public in the country where the alleged infringement is actually claimed to have occurred. Particularly in trade mark law, evidence of the latter type is regularly far more relevant than that of the defendant's physical actions: for assessing a likelihood of confusion, the perception of the target public - whether the marks are considered to be orally or conceptually similar ${ }^{28}$ - or the degree of distinctiveness a mark has gained on the relevant market ${ }^{29}$ are regularly of primary importance. Similar considerations apply with regard to unfair use being made of a mark's reputation which may exist in that particular part of the EU market only ${ }^{30}$ - or the effect of limitations - which may be impacted by linguistic specificities of the target market. ${ }^{31}$ Thus, the courts in any country where the mark is actually used in commerce, and where according to the plaintiff the infringement occurs, are "best placed" to assess the conflict within that particular territory, ${ }^{32}$ irrespective of whether or not the defendant is physically present there.

The consequences of limiting the competent venue to the place of physical action are particularly awkward in view of the conjunction between Arts. 125(5) and 126(2) EUTMR. The latter provision limits the competence of courts seized on the basis of Art. 125(5) to "acts committed or threatened within the territory of the Member State in which that court is situated". Assuming that the term "act" in

\footnotetext{
${ }^{28}$ Established case law. For an example of perceptions being influenced by the linguistic and cultural background of the public in different Member States, see CJEU C-361/04 P - Claude Ruiz-Picasso et al v. OHIM (Picasso/Picaro). See also C-252/12, ECLI:EU:C:2013:497 - Specsavers v. Asda Stores, where the CJEU confirmed that account could be taken for the assessment of infringement that the mark had been used on the national market in a particular colour.

${ }^{29}$ Established case law since CJEU C-39/97 ECLI:EU:C:1998:442 - Canon Kabushiki Kaisha v. MetroGoldwyn-Mayer (Canon/Cannon), para. 18 (explaining that the distinctiveness of marks can exist either per se or because of the reputation they possess on a given market).

${ }^{30}$ See e.g. CJEU C-301/07 P, ECLI:EU:C:2009:611 - Pago v. Tirolmilch.

${ }^{31}$ See e.g. CJEU C-235/09, ECLI:EU:C:2011:238 - DHL Express France v. Chronopost.

${ }^{32}$ It is important to keep in mind in this context that a plaintiff choosing the venue under Art. 125(5) can and will only seek redress in regard to the conflict within that particular territory. Thus, the situation in other Member States does not, and cannot, play a role. This is different from proceedings before courts with general jurisdiction where the situation in other countries can be invoked by the plaintiff as well as by the defendant to bolster the respective claims.
} 
Art. 126(2) must be interpreted synonymously with "act of infringement", 33 this would mean that if the infringer's target market(s) are located in other Member States than the one where he is present, there is no possibility for the court seized to take account of the infringements actually committed insofar as they occur abroad. And as the infringer is not physically present on the foreign markets, there is also no possibility for the right holder to seek redress in the countries where the mark is massively infringed. In the light of sound administration of justice, imposing such restrictions appears to be a rather counter-intuitive move.

It is true that if the defendant is commercially active in other markets than where he is physically present, the gap left by a "physical action"-centred approach to Art. 125(5) EUTMR can be filled in practice by instigating proceedings at a venue having central jurisdiction. However, as was pointed out above (2.3), that solution is tantamount to a nearly complete emasculation of the provision; it becomes all but meaningless vis-à-vis Art. 125(1), or is even entirely inapplicable if the defendant acts from outside the EU. This clashes with the principle otherwise observed by the CJEU that provisions allocating special jurisdiction should be given a proper scope of application; they should not be interpreted so that they nearly completely overlap with rules of general jurisdiction, ${ }^{34}$ let alone become inapplicable in a sizeable number of cases.

\subsubsection{Diminishing the Risk for Counterclaims?}

Courts competent to hear and decide on infringement of EU marks on the basis of Art. 125(5) EUTMR are also competent to declare an EU mark invalid if the defendant raises a counterclaim. Whereas infringement jurisdiction is territorially limited, the unitary character of EU marks precludes such limitations in case of a positive finding on the counterclaim: if the mark is found invalid, the judgment has Union-wide effect. In view of such seemingly imbalanced consequences it might be considered appropriate to lower the risk of courts with territorially restricted jurisdiction adjudicating on validity. Introducing additional qualifications such as the requirement of the defendant's physical presence might possibly contribute to that aim.

On the other hand, if such concerns were of crucial weight one would expect that the competence to adjudicate on (in)validity is denied altogether to courts having only territorially limited jurisdiction. However, no such step was taken by the legislature, signalling that the consequences of an infringement court adjudicating on invalidity with EU-wide effect were considered to be acceptable in principle. Before that backdrop it is not plausible why the physical presence of the defendant in the forum state should be of relevance: there is no conceivable reason why courts

\footnotetext{
${ }^{33}$ The same applies vice versa, that is, if "act of infringement" is interpreted as "an act liable to cause infringement", without further qualifying elements being added, Art. 126(2) EUTMR must be interpreted accordingly, meaning that the court seized is competent to adjudicate on the infringement occurring in its own territory.

${ }^{34}$ Inter alia this was the reason why the CJEU in case 21/76, ECLI:EU:C:1976:166 - Bier v. Mines de Potasse came to the conclusion that tort jurisdiction should be available at the place of the act and the place where the effect arose.
} 
at the defendant's place of physical action should be in a better position to assess invalidity than courts at other places of infringement. It could even be the other way round: depending on the circumstances, courts in the country of actual infringement could have more direct access to (e.g. linguistic) peculiarities on which a counterclaim for lacking distinctiveness or other obstacles to protection might be founded.

\subsubsection{Preliminary Conclusion}

Summing up, the legal history as well as other elements pertaining to the purpose and context of Art. 125(5) advise against curtailing the jurisdictional options by imposing a requirement of the defendant's physical presence. This only leaves the wording ("act"), in combination with the CJEU's reluctance to detach its reasoning from tort jurisdiction with its dichotomy of "act" and "effect" established under the Brussels system. However, as was shown above, a truly autonomous interpretation conceptualising "act of infringement" as a notion of intellectual property law leads to the conclusion that the wording is ambiguous: it may refer to an "initial (physical) action" triggering further infringements in other territories and to an (individual) "infringing act", which conforms to the prerequisites of an infringement committed within the state where it occurs. Thus, the wording requires a choice to be made between the interpretative options instead of offering secure guidance; the solution can only be derived from other, external factors. In that situation, the choice appears clear: as was shown above, a qualification in the sense of the defendant physically acting in the forum state is neither called for nor appropriate; it obstructs rather than serves the goal of sound administration of justice and efficacious conduct of proceedings.

\subsection{Article 7(2) Brussels I ${ }^{\mathrm{a}}$ and Art. 125(5) EUTMR: Levelling the Differences?}

In the light of what is said above, the CJEU's finding in Coty that claims for infringement of an EUTM can only be filed at the place of acting should preferably be interpreted in the sense that competence under Art. 125(5) is vested in the courts at the place or the places where the defendant has acted in an allegedly infringing manner. The benchmark for such acts liable to cause infringement is found in the use modalities listed in Art. 9(3) EUTMR; physical presence of the defendant is not required.

This is exactly how the provision was interpreted by the Munich court of appeal in the Perfume Marks case. ${ }^{35}$ The court found it necessary, but also sufficient, that the plaintiff brought forth substantiated claims that the defendants' conduct amounted to (infringing) use in the course of trade within the territory of Germany. Based on that approach the court dismissed the defendants' argument that offering goods for sale vis-à-vis the company H.P. was not an act of infringement, but only constituted the effect of such an act. The appeal court's reasoning in that regard is

\footnotetext{
35 Supra note 8.
} 
supported by the fact that in national ${ }^{36}$ and CJEU case law $^{37}$ it is uncontentious that sales offers and other conduct aimed at distribution of goods into a specific territory amount to acts of infringement committed there.

The approach taken by the Munich court of appeal - which is also endorsed in this article - re-aligns the parameters governing tort jurisdiction under Art. 7(2) Brussels I ${ }^{\mathrm{a}}$ and Art. 125(5) EUTMR to some extent. However, this does not result in a complete levelling of differences between the two provisions. Thus, the fact remains that in the situation underlying the Coty decision no infringement claim can be brought against the participant in an infringement committed in Germany whose proper conduct was confined to a foreign territory. ${ }^{38}$ Furthermore, under Art. 7(2) Brussels $\mathrm{I}^{\mathrm{a}}$ the CJEU has endorsed very generous standards for establishing tort jurisdiction at the "place of effect". This means that in intellectual property litigation it is only required to show that the right is protected in the Member State where the court is located ${ }^{39}$ and that an abstract possibility of infringement exists. For instance, in case of infringements committed on the internet it suffices if impugned content is technically accessible; ${ }^{40}$ it is not necessary for the plaintiff to claim that the defendant infringed the right, or participated in an infringement, within the forum state. ${ }^{41}$ This means that in the situation underlying the Perfume Marks decision, jurisdiction of the German courts to assess the infringement of German marks or IR marks protected with effect for Germany could have been established by referring to the accessibility of the defendants' website, irrespective of the fact that it was neither interactive nor directed at the German public.

In contrast, stricter preconditions apply for establishing jurisdiction based on Art. 125(5) EUTMR. As pointed out above, it is a necessary prerequisite that the plaintiff brings forth substantiated claims that the defendant has acted in a manner that qualifies as infringing use - and thereby as an act of infringement - pursuant to Art. 9(3) EUTMR within the territorial ambit of adjudicative competence assigned to the court seized.

Based on that differentiation, the CJEU's dictum in Coty that the dual linking factors of "act" and "effect" only apply within the framework of Art. 7(2) Brussels $\mathrm{I}^{\mathrm{a}}$ and not in the context of Art. 125(5) EUTMR can be observed without inappropriately restricting the remit of the latter provision.

\footnotetext{
${ }^{36}$ BGH, decision of 5 November 2015, case No. I ZR 76/11 - Wagenfeld-Leuchte (Wagenfeld Lamp) (copyright).

37 CJEU case C-5/11, ECLI:EU:C:2012:370 - Donner (copyright); C-98/13, ECLI:EU:C:2014:55 Blomqvist (trade mark).

38 This was the situation in the dispute underlying the Coty decision; see supra. It is true that, even in that case, the opinion could be endorsed that if he was involved in the plan the defendant should be amenable to court action in Germany (see to that effect A. Kur, JIPLP, supra note 21). However, as the defendant himself did not engage in "use in the course of trade" of the mark in Germany, the opposite opinion endorsed by the CJEU appears acceptable.

39 CJEU case C-523/10, ECLI:EU:C:2012:220 - Wintersteiger, paras. 25, 27; C-360/12, ECLI:EU:C:2014:1318 - Coty, para. 55 (concerning national rights).

40 CJEU case C-170/12, ECLI:EU:C:2013:635 - Pinckney, paras. 43, 44.

41 This was the situation in CJEU case C-170/12, ECLI:EU:C:2013:635 - Pinckney; see summary of the underlying dispute.
} 


\subsection{Homogeneous Application of Art. 8(2) Rome II and Art. 125(5) EUTMR?}

The BGH did not invoke Coty in its Perfume Marks judgment; the argument made by the Munich court of appeal that the defendants did engage in "active conduct" by placing their offer to a German firm was neither denied nor discussed. Instead the BGH relied on Nintendo and the CJEU's definition of what constitutes a causal event within the meaning of Art. 8(2) Rome II. Based on the similar wording and the principle of legal certainty the court concluded that the definition must be exactly the same in both provisions. As was argued above, this does not take sufficient account of the specific purpose and context of determining infringement jurisdiction within the framework of the EUTMR. It is also not supported by the Nintendo decision itself: the CJEU distinguishes between (multiple) "acts of infringement" and the overall assessment of a chain of events leading to such infringements in order to identify their place of origin. ${ }^{42}$ This rather indicates that "act(s) of infringement" and "(initial) event giving rise to the damage" are defined and assessed independently of each other.

There is indeed no reason why the relevant concepts must be interpreted uniformly under all circumstances. On the contrary: even under Art. 8(2) Rome II, where the overall assessment commanded by Nintendo usually leads to satisfactory results, the interpretation cannot be invariably the same regardless of context. Think of the situation where the infringer acts from a non-EU country. As was pointed out above, under the approach endorsed by the BGH, Art. 125(5) EUTMR would be inapplicable in such situations, which is awkward yet tolerable. Worse than that, an invariable, stringent determination of the applicable law based on the concept of "initial event" would subject the relevant issues (e.g. computation of damages) to non-EU law. Although the Rome II Regulation does not exclude the application of non-EU law per se, accepting such effects in this particular case would openly clash with the principle that non-contractual obligations resulting from infringement of intellectual property rights cannot be governed by any other law than the lex protectionis. $^{43}$ In order to avoid inacceptable results, the reference in Art. 8(2) Rome II to "act of infringement" must therefore be understood as pertaining in such cases to the law of the Member State(s) where individual infringing acts are performed, and not to the law at the place of the initial event originally causing those infringements.

This demonstrates again the ambiguity inherent in the term "act of infringement": rather than expressing a fixed, unequivocal concept, it can be interpreted both as an "initial event causing further infringements" and/or as "conduct fulfilling the legal requirements of an infringement". Which of these interpretative options is

\footnotetext{
${ }^{42}$ Nintendo (supra note 3). See, for instance, the third prong, second sentence, in the operative part of the judgment: "Where the same defendant is accused of various acts of infringement in various Member States, the correct approach for identifying the event giving rise to the damage is not to refer to each alleged act of infringement, but to make an overall assessment of that defendant's conduct in order to determine the place where the initial act of infringement at the origin of that conduct was committed or threatened by it."

${ }^{43}$ See e.g. Art. 8(3) Rome II Regulation, which is the only provision in the Regulation that precludes any choice of law by the parties.
} 
governing cannot be decided by way of abstract exegesis, but depends on contextual considerations. Regarding Art. 8(2) Rome II, the primary option for interpretation is that of "initial event" identifying the law most closely connected with the infringement in its entirety, whereas the second interpretative option provides a fallback position in the case that the infringements were initialised from a non-EU country. Regarding Art. 125(5) EUTMR, the second interpretative option should always prevail, as only in that way is it possible to do justice to the aim and purpose of the provision to establish a decentralised, flexible alternative to the central venues of jurisdiction listed in Art. 125(1)-(4).

\section{What Can Be Done?}

The BGH's Perfume Marks decision provides an unfortunate example of how overinterpretation of CJEU judgments can produce flawed results. The repercussions in practice are serious, at least in Germany: although BGH decisions do not form binding precedents in the German legal system, they do have considerable authority that cannot be ignored by district courts and courts of appeal. However, it is possible that such courts, in view of the grave consequences, decide to turn to the CJEU for clarification and, possibly, correction of the BGH's ruling. It is true that the BGH has claimed that such a referral is unnecessary, but the reasoning on this point is as unconvincing as the judgment in its entirety. Contending that "without doubt" the criteria for determining the applicable law under Art. 8(2) Rome II must be exactly the same as those identifying the competent court under Art. 125(5) EUTMR ignores the structural and contextual differences between the two provisions. It also pays no attention to the fact that the CJEU itself distinguishes between "acts of infringement" occurring in multiple Member States and the concept of the "initial event" underlying the determination of a single applicable law. This alone would have been reason enough to ask the CJEU for clarification. It is therefore more than welcome that, so soon after the unfortunate Perfume Marks decision, the Court of Appeal for England and Wales reacted by referring to the CJEU exactly those questions that the $\mathrm{BGH}$ chose to ignore. ${ }^{44}$

Acknowledgements Open access funding provided by Max Planck Society. The author wants to thank Dr. Lydia Lundstedt, University of Stockholm, for valuable input to an earlier version of this article.

Open Access This article is distributed under the terms of the Creative Commons Attribution 4.0 International License (http://creativecommons.org/licenses/by/4.0/), which permits unrestricted use, distribution, and reproduction in any medium, provided you give appropriate credit to the original author(s) and the source, provide a link to the Creative Commons license, and indicate if changes were made.

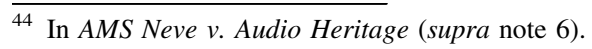




\section{Reference}

Kur A (2015) Enforcement of unitary intellectual property rights: international jurisdiction and applicable law. JIPLP 10:468-480 